\title{
Zulfiqar Frailty Scale: Overview, Stakes, and Possibilities
}

\author{
Abrar-Ahmad Zulfiqar *(D) and Ibrahima Dembélé \\ Service de Médecine Interne, Diabète et Maladies Métaboliques de la Clinique Médicale B, \\ Hôpitaux Universitaires de Strasbourg et Equipe EA 3072 “Mitochondrie, Stress Oxydant et Protection \\ Musculaire", Faculté de Médecine-Université de Strasbourg, 67000 Strasbourg, France; \\ ibrahimaadembele@gmail.com \\ * Correspondence: abzulfiqar@gmail.com
}

check for

updates

Citation: Zulfiqar, A.-A.; Dembélé, I. Zulfiqar Frailty Scale: Overview, Stakes, and Possibilities. Medicines 2021, 8, 73. https://doi.org/10.3390/ medicines 8120073

Academic Editor: Emmanuel Andrès

Received: 25 October 2021

Accepted: 16 November 2021

Published: 23 November 2021

Publisher's Note: MDPI stays neutral with regard to jurisdictional claims in published maps and institutional affiliations.

Copyright: (c) 2021 by the authors. Licensee MDPI, Basel, Switzerland. This article is an open access article distributed under the terms and conditions of the Creative Commons Attribution (CC BY) license (https:// creativecommons.org/licenses/by/ $4.0 /)$.

\begin{abstract}
Very few frailty scales are used by general practitioners, as they are time consuming and cumbersome. We developed a frailty screening tool for use in primary care, referred to as the Zulfiqar Frailty Scale (ZFS). This scale was tested in multiple general practitioners' offices in France, and these studies were published. In this paper, we offer a summary of these results.
\end{abstract}

Keywords: Zulfiqar Frailty Scale (ZFS); frailty syndrome; primary care

\section{Introduction and Development}

According to the French National Institute of Statistics and Economic Studies (INSEE), 13.1 million people were aged 65 or older in France in 2018, or one in five inhabitants. By 2070 , it is estimated that seniors will represent $29 \%$ of the French population. France's elderly population has been growing steadily since 2011, or the year in which the first children of the baby boom generation turned 65. The year 2021 marks the end of the rise in 65-74 year-olds, as this is the year that all "baby boomers" will have reached the age of 65. The number of seniors aged 75-84 will increase from 2021 onwards, and from 2031 onwards for those aged 85 and over. Because of the increase in life expectancy, this aging of the population should continue until 2050 for 75-84 year-olds, and until 2060 for those aged 85 and over. After this time, the post-baby boom generations will contribute to a stabilization in the rise in the number elderly people in the population [1].

The stakes are high with regard to public health, as elderly people are at risk of chronic diseases, decompensation, a loss of autonomy, and (as a consequence) repeated recourse to care and hospitalization. As a society, we must therefore be proactive to prevent the healthcare system from becoming saturated and to improve the quality of life of patients. There are many different ideas as to what constitutes frailty in the elderly. Nevertheless, most literature reviews portray frailty as a dynamic and evolving concept that affects several aspects of daily life and may lead to a loss of autonomy [2]. Frailty cannot be reversed spontaneously. However, it can be reversed with targeted and proactive measures designed to bring about a reduction in morbidity and mortality [3].

General practitioners are often the first point of contact for care, and are therefore best suited to detect and implement the necessary actions to reverse frailty. There are many different scales for diagnosing frailty. However, these scales usually go beyond the scope of a general consultation. For example, the Fried Index (gold standard) requires the use of a dynamometer, a tool that is missing from most doctors' offices. Moreover, sufficient space is required to allow patients to walk in a straight line (and thus measure their walking speed). As we can see from this example, certain scales are both technical and extremely time-consuming. Given the limited resources available to primary care providers, we decided to create a new frailty detection scale for use by general physicians. Unfortunately, these limited resources have become part of the undeniable and growing problem of frailty in the elderly, a major public health issue that is sure to remain problematic for many years to come. We developed a frailty screening tool that standardizes professional procedures 
and makes it possible for general practitioners to detect frailty in their elderly patients. This frailty scale (known as the "ZULFIQAR" scale) was created in an outpatient setting in conjunction with general physicians and tested for the first time in Plancoët in Brittany (Table 1). It includes six items which (as per the medical literature) are significantly and independently associated with a poor prognosis in terms of mortality and morbidity, and which can therefore be defined as frailty markers [4-9]. They were also chosen due to their simplicity and ability to be implemented quickly, since none of the items requires special equipment or prior training by the healthcare professional. The items were formulated as questions. A point is tallied for each positive response ("yes"). The patient is considered "non-frail" if their score is equal to 0 , "not very frail" if their score is equal to 1 or 2 , and "frail" if their score is greater than or equal to 3 .

Table 1. Zulfiqar Frailty Scale: ZFS.

\begin{tabular}{ccc}
\hline Cotation & $\mathbf{1}$ & $\mathbf{0}$ \\
\hline Is there a weight loss greater than or equal to 5\% in 6 months? & Yes & No \\
Monopod support test $<5$ s? & Yes & No \\
Does the person live alone? & Yes & No \\
Does the patient receive home care? & Yes & No \\
Does the person complain of memory loss? & Yes & No \\
$\begin{array}{c}\text { Does the person have prescriptions for more than 5 therapeutic } \\
\text { classes on his/her prescription history for at least 6 months? }\end{array}$ & Yes & =1-2: pre frail \\
Total/6 & 3: frail \\
\hline
\end{tabular}

\section{Main Results}

Our frailty screening scale has been the subject of several published (or soon-to-bepublished) studies since the original article was published in the journal MEDICINES MDPI. The results of the proof-of-concept study were very satisfactory and reproducible, and similar results have been found in subsequent trials. A simplified scale derived from the Zulfiqar Frailty Scale (sZFS) was created with five items (only one question regarding social interactions; the item "Does the patient benefit from home care?" was removed).

Table 2 below illustrates the main results of the various studies.

Table 2. Summary of the characteristics of the different studies and populations.

\begin{tabular}{|c|c|c|c|c|c|}
\hline & $\begin{array}{c}\text { Creation of a New } \\
\text { Frailty Scale in } \\
\text { Primary Care: } \\
\text { ZFS [5] }\end{array}$ & $\begin{array}{l}\text { Frailty in Primary } \\
\text { Care Validation of } \\
\text { the sZFS * }[10]\end{array}$ & $\begin{array}{l}\text { Validation of the } \\
\text { Zulfiqar Frailty } \\
\text { Scale (ZFS): A New } \\
\text { Tool for General } \\
\text { Practitioners [11] }\end{array}$ & $\begin{array}{l}\text { Validation of a } \\
\text { New Frailty Scale } \\
\text { in Primary Care: } \\
\text { The sZFS * [12] }\end{array}$ & $\begin{array}{c}\text { Creation of a New } \\
\text { Frailty Scale in } \\
\text { Primary Care: } \\
\text { The ZFS * [13] }\end{array}$ \\
\hline Populati on & $\geq 75 y, \mathrm{ADL}^{*} \geq 4$ & $\geq 65 \mathrm{y}, \mathrm{ADL}^{*} \geq 4$ & $\geq 65 \mathrm{y}, \mathrm{ADL}^{*} \geq 4$ & $\geq 65 \mathrm{y}, \mathrm{ADL}^{*} \geq 4$ & $\geq 75 \mathrm{y}, \mathrm{ADL}^{*} \geq 4$ \\
\hline Localization & Brittany & Normandy & Alsace & $\begin{array}{l}\text { Champagne- } \\
\text { Ardennes }\end{array}$ & Poitou-Charente \\
\hline Inclusion period & $\begin{array}{c}1 \text { November 2018- } \\
30 \text { April } 2019\end{array}$ & $\begin{array}{c}1 \text { November 2017- } \\
1 \text { April } 2018\end{array}$ & $\begin{array}{l}1 \text { November 2020- } \\
30 \text { April } 2021\end{array}$ & $\begin{array}{l}2 \text { May 2019- } \\
30 \text { April } 2020\end{array}$ & $\begin{array}{l}1 \text { May 2019- } \\
30 \text { May } 2020\end{array}$ \\
\hline $\begin{array}{l}\text { Number of } \\
\text { elderly patients } \\
\text { included }\end{array}$ & 102 patients & 107 patients & 102 patients & 268 patients & 200 patients \\
\hline Male & 47 & 43 & 47 & 143 & 97 \\
\hline Female & 55 & 64 & 55 & 125 & 103 \\
\hline Age & $82.65(4.79)$ & $74(7)$ & $75.9(8)$ & $77.5(7.8)$ & $81.4(4.82)$ \\
\hline $\mathrm{ADL}^{*} / 6$ & $5.39(0.73)$ & $5.87(0.34)$ & $5.83(0.35)$ & $5.60(0.90)$ & $5.81(0.53)$ \\
\hline $\mathrm{IADL}^{*} / 8$ & $5.52(2.57)$ & $7.65(0.85)$ & $7.04(1.68)$ & $\begin{array}{l}0.72(1.08) \\
(\text { IADL/4) }\end{array}$ & $6.19(1.58)$ \\
\hline $\begin{array}{c}\text { Charlson } \\
\text { comorbidities } \\
\text { index }\end{array}$ & 3.08 (1.87) & 4.38 (1.99) & $4.11(1.81)$ & $2.43(1.92)$ & $4.63(1.01)$ \\
\hline
\end{tabular}


Table 2. Cont.

\begin{tabular}{|c|c|c|c|c|c|}
\hline & $\begin{array}{c}\text { Creation of a New } \\
\text { Frailty Scale in } \\
\text { Primary Care: } \\
\text { ZFS [5] }\end{array}$ & $\begin{array}{l}\text { Frailty in Primary } \\
\text { Care Validation of } \\
\text { the sZFS * [10] }\end{array}$ & $\begin{array}{l}\text { Validation of the } \\
\text { Zulfiqar Frailty } \\
\text { Scale (ZFS): A New } \\
\text { Tool for General } \\
\text { Practitioners [11] }\end{array}$ & $\begin{array}{l}\text { Validation of a } \\
\text { New Frailty Scale } \\
\text { in Primary Care: } \\
\text { The sZFS * }[12]\end{array}$ & $\begin{array}{c}\text { Creation of a New } \\
\text { Frailty Scale in } \\
\text { Primary Care: } \\
\text { The ZFS * [13] }\end{array}$ \\
\hline Drugs number & $6.37(2.78)$ & $5.1(2.9)$ & $\begin{array}{c}4.3(3.0) \\
\text { (Therapeutic class) }\end{array}$ & $7.59(3.84)$ & $\begin{array}{c}6.32(3.6) \\
\text { (Therapeutic class) }\end{array}$ \\
\hline Compared with & $\begin{array}{c}\text { Fried } \\
\text { Modified SEGA * } \\
\text { scale } \\
\text { GFST }^{*} \text { scale } \\
\text { CGA }^{*}\end{array}$ & GFST * scale & Modified SEGA scale & Fried & Fried \\
\hline $\begin{array}{l}\text { Duration time } \\
\text { ZFS */sZFS * } \\
\text { (seconds) }\end{array}$ & 109.62 & 77 & 92.75 & 110 & 71.7 \\
\hline
\end{tabular}

* ADL: activity of daily living; y: years; sZFS: simplified Zulfiqar Frailty Scale; ZFS: Zulfiqar Frailty Scale; GFST: Gérontopôle Frailty Screening Tool; SEGA: Short Emergency Geriatric Assessment; IADL: Instrumental Activity of Daily Living; CGA: Comprehensive Geriatric Assessment. Data expressed as: mean (standard deviations).

\section{Discussion and Perspectives}

In the various studies that were conducted, it took less than 2 min to complete the test. The scale is therefore ideal for an outpatient setting. Physicians are provided with all the necessary information on the patient's treatments, social interactions, and nutrition. Each item in the questionnaire can potentially score one point, for a total of six points. The elderly person is considered "frail" by our ZFS scale if they score 3 or higher. For scores of 1 or 2, the patient is considered "pre-frail." For a score of 0 , the elderly person is considered "non-frail" or "robust."

The results of the studies are very satisfactory: the correlations between the Zulfiqar Scale (and the simplified scale) and other frailty scales are very satisfactory.

In addition, the areas under the curve ranged from 0.80 to 0.94 .

These results show that the ZFS and sZFS are outstanding tools for detecting frailty.

A future study will assess the ability of our ZFS frailty screening tool to predict the onset of morbidity and mortality within 6 months for a group of elderly subjects monitored by general practitioners, in particular with regard to falls, fractures, unscheduled hospitalizations (including emergency room visits), a loss of autonomy, institutionalization, and death. The study will begin in the Champagne-Ardenne and Normandy regions of France.

Our scale could also be used in doctors' offices and multidisciplinary clinics, where the detection of frailty can be accompanied by targeted measures thanks to the many healthcare professionals present. Considering the shortage of frailty clinics and geriatricians, this could prove extremely beneficial. Naturally, general physicians will be able to create personalized treatment plans and play a central role in the care of their patients. They will coordinate with paramedical and social professionals, reassess care options, and help manage family caregivers. It is estimated that $30 \%$ to $40 \%$ of elderly people living at home are frail.

Given the scope of this syndrome and (in certain areas) the shortage of qualified physicians, local paramedical professionals (private nurses, physiotherapists, pharmacists, etc.) must also be able to screen for frailty. We have therefore set up a website that can be accessed by all medical professionals (as well as paramedical professionals such as home care nurses, occupational therapists, and physical therapists) from anywhere. This website is available at the following link: http:/ / zulfiqarfrailtyscale.com/ (accessed on 1 June 2021). A mobile app will also be released soon. 
Author Contributions: Conceptualization, A.-A.Z.; methodology, A.-A.Z.; software: A.-A.Z.; validation, A.-A.Z., I.D.; formal analysis, A.-A.Z.; investigation, A.-A.Z.; resources, A.-A.Z.; data curation, A.-A.Z.; writing-original draft preparation, A.-A.Z.; writing-review and editing, A.-A.Z., D.I.A.; visualization, A.-A.Z., I.D.; supervision, A.-A.Z.; project administration, A.-A.Z. All authors have read and agreed to the published version of the manuscript.

Funding: This research received no external funding.

Institutional Review Board Statement: Not applicable.

Informed Consent Statement: Not applicable.

Data Availability Statement: Not applicable.

Conflicts of Interest: The authors declare no conflict of interest.

\section{References}

1. De 2,8 Millions De Seniors En 1870 En France à 21,9 Millions En 2070?-France, Portrait Social I Insee. Available online: https: / / www.insee.fr/fr/statistiques/3645986?sommaire=3646226 (accessed on 3 October 2021).

2. Zulfiqar, A.-A.; Seng, X.S.; Kadri, N.; Doucet, J.; Hajjam, M.; Hajjam, A. La fragilité du sujet âgé: Un concept majeur au cœur de l'actualité en gériatrie Revue de littérature. Médecine Thérapeutique 2017, 23, 223-228.

3. Monteserin, R.; Brotons, C.; Moral, I.; Altimir, S.; San, J.A.; Santaeugenia, S. Effectiveness of a geriatric intervention in primary care: A randomized clinical trial. Fam. Pract. 2010, 27, 239-245. [CrossRef] [PubMed]

4. Fried, L.P.; Tangen, C.M.; Walston, J.D.; Newman, A.B.; Hirsch, C.; Gottdiener, J.S. Frailty in Older Adults: Evidence for a Phenotype. J. Gerontol. Ser. A Boil. Sci. Med. Sci. 2001, 56, M146-M157. [CrossRef] [PubMed]

5. Zulfiqar, A.A. Creation of a New Frailty Scale in Primary Care: The Zulfiqar Frailty Scale (ZFS). Medicines 2021, 13, 19. [CrossRef] [PubMed]

6. Nourhashémi, F.; Rolland, Y.; Vellas, B. La prévention des chutes et de leurs conséquences. Presse Méd. 2000, 29, 1249-1254.

7. Sternberg, S.A.; Schwartz, A.W.; Karunananthan, S.; Bergman, H.; Mark, C.A. The Identification of Frailty: A Systematic Literature Review. J. Am. Geriatr. Soc. 2011, 59, 38. [CrossRef] [PubMed]

8. Kojima, G. Frailty as a predictor of disabilities among community-dwelling older people: A systematic review and meta-analysis Disabil. Rehabil. 2017, 39, 1897-1908. [CrossRef]

9. Kojima, G.; Kendrick, D.; Skelton, D.A.; Morris, R.W.; Gawler, S.; Iliffe, S. Frailty predicts short-term incidence of future falls among British community-dwelling older people: A prospective cohort study nested within a randomised controlled trial. $B M C$ Geriatr. 2015, 2, 155. [CrossRef]

10. Zulfiqar, A.A. Frailty in Primary Care: Validation of the simplified Zulfiqar Frailty Scale (sZFS). Medicines 2021, 3, 51. [CrossRef] [PubMed]

11. Zulfiqar, A.A. Validation of the Zulfiqar Frailty Scale (ZFS): A New Tool for General Practitioners. Medicines 2021, 4, 52. [CrossRef]

12. Zulfiqar, A.A. Validation of a new frailty scale in primary care: The simplified Zulfiqar frailty scale. Transl. Med. Aging 2021, 5, 39-42. [CrossRef]

13. Zulfiqar, A.A. Creation of a new frailty scale in primary care: The Zulfiqar frailty scale. Casp. J. Intern. Med. 2021, in press. 